\title{
Geolocation Mobile Application to Create New Routes for Cyclists
}

\author{
Jesús F. Lalupú Aguirre \\ University of Sciences and Humanities \\ Faculty of Sciences and Engineering \\ Lima Peru
}

\author{
Laberiano Andrade-Arenas \\ University of Sciences and Humanities \\ Faculty of Sciences and Engineering \\ Lima Peru
}

\begin{abstract}
In Peru in recent decades it has undergone unexpected changes, often generating chaos among the population, such as the excess of vehicles that travel daily on the roads generating pollution. This has led people to seek alternatives, such as the use of bike, as a means of transportation. The objective is develop a mobile application for the creation of alternative routes for cyclists. For them we have carried out a survey of 50 people dedicated to the field of cycling as well as people who do not exercise it in order to collect data, analyze it and create mechanisms that help these users. This application was developed in Android Studio implementing free libraries to achieve its geolocation in a way that provides all the facilities for the cyclist to move. For the process of creating this application, the Scrum methodology was used, the design of the prototype is done in Adobe Photoshop. It was obtained as results of the investigation carried out in the survey that $75 \%$ of the people are satisfied with the use of the application, $60 \%$ responded defining it as very good and $100 \%$ answered yes they would recommend the application.The investigation is of importance, since it would allow as future work the reduction of environmental contamination.
\end{abstract}

Keywords-Android studio; cyclists; mobile application; geolocation; scrum

\section{INTRODUCTION}

During the years the vehicular influx has collapsed in the Peru is faced with a large-scale social problem, of a critical and unsustainable nature [1]. In addition to this, the crisis would saturate as a result of the covid-2019 that paralyzed the whole world submerging people to distance themselves between families, friends and society [2]. This has motivated many people who usually made use of public transport and in some cases private transport seek other alternatives with which they can move to their jobs, carry out their recreational activities among other.

Cyclists in turn have merged their transport tool and have originated the cyclotourism activity that has been developing rapidly in recent months, and even so there is the possibility of considerable growth in the coming months, which has been reflected in the purpose of purchase and search of bicycles by customers [3]. This has generated that friends, athletes, users get together to visit tourist places in the capital as well as recreational spaces located in different parts of the city for recreational or sports purposes. That somehow seek to spread this activity that in some way is an alternative to city vehicular chaos [4].

In the development of this research, a mobile application oriented to the use of this minor means of transport has been created, a mechanism that help people who have a mobile device and a bicycle to move around the city without the fear that many times invades us like the fear of buses, taxis, trucks or any high-speed vehicle including linear motorcycles, traveling on vehicular roads due to lack of bicycle lanes, the fear of being run over, also nerves when driving and robberies.

The main reason for this research development is based on the fundamental problems generated by the lack of bicycle infrastructure, the lack of information that users have to face in a complicated scenario due to the lack of bicycle paths, dangerous crossings, the lack of signage and obstacles. during the tour.

Consequently, the research carried out on this problem on the bicycle as a means of transport was the result of the increase of this means in recent months. As well as the interesting ideas that have for carrying out the application, giving it added value in its basic functions in which it will perform, such as the search for bicycle lanes in the city, the location on the map and navigation during the transfer from point A to point $\mathrm{B}$.

For the development of this research, the Scrum methodology was used as a framework [5] [6], which was used as a reference for the development of this project, with the main objective of implementing a mobile application in order to create new cycling routes in metropolitan Lima. Research contributes to solving problems such as vehicular chaos for some users, contributing to tourism in the city, increasing sales of stores dedicated to this area.

The article is made up of the following sections: in Section II, the review of the literature where the different investigations are analyzed; in Section III, the methodology was used, which allowed sequencing the steps to be carried out; in Section IV, results and discussions of the investigation; and the section $\mathrm{V}$ conclusions; the Section VI future work.

\section{LiterATURE REVIEW}

The following project aims to generate guidelines and indications for the development of a mobile application implemented with the Global Positioning System (GPS) oriented to cyclists in the city of metropolitan Lima, Due to the high demand for bicycles and skateboards / scooters in the city as a result of the excess of automotive transport, also with the use of smartphones and the GPS navigation system that is a very helpful tool that for the trip is more efficient and agile, 
informing them about the routes predetermined by the search engine, it also shows the alternate routes from the city, the main points of interest and tourist attractions.

According to the authors [7], Law $\mathrm{N}^{\circ} 30936$ decreed by the Peruvian state and the actions taken by the municipality of metropolitan Lima refer that this law is fundamental for the project, as it reflects the fundamental axis on the evolution of the bicycle as a means of transport, providing improvements so that the bicycle lane network, committing itself to the growth of this network in the short and long term. The author [8] used the Scrum methodology for the development of your project, using the Android operating system because it has $72.6 \%$ of the Peruvian market, important data for the research.

Meanwhile the author [9], it refers that in Peru, given the existence of the need of the unsatisfied market to which it is directed, the project of mobile applications for cyclists is a satisfactorily valuable tool and that also the bicycle as a means of transport is an issue to be deepened due to the current situation of the country.

What's more [10], indicates that this social problem should not only be treated like any innovation project, but also from the legal framework starting from the literature review because the analytical-synthetic method is used in addition to employing a qualitative analysis with the use of interviews to expert to complement the research and get a better focus. As well as [11], concludes that in addition to being an innovation tool to be used, the objective will be to carry out educational campaigns and workshops on the advantages and disadvantages of using bicycles as a means of transport focused mainly on schools and universities, as well as work centers in order to better project information and not minimize the risks of insecurity.

For the author [12], mentions that during the last decade mobile devices the world has become an important technological tool for society so much so that it has been transformed from a normal computer to something so small that can carry it in the pocket which at the same time allows us to perform various operations. In addition to contributing to the development of society, in an educational and cultural way.

In the research carried out by the aforementioned authors, they determine the importance of the implementation of this application as a facilitating means for cyclists dedicated to sports, businesses or any natural person who sees in the bicycle an alternative of urban transport. During the research processes, some of the authors mentioned did not take the problem on a large scale as the problem of environmental pollution that could decrease with the use of bicycles, but instead focused on the increase in tourism as a benefit for the private sectors dedicated to to the bicycle industry and not as a good for the entire Peruvian society. That is why the research work was carried out focusing on being able to use the mobile application to be able to create alternative routes for itself to contribute in giving improvements to the society as pollution reduction and reduce excess traffic.

\section{Methodology}

For the research work, the Scrum methodology was applied as it is an agile methodology that allows us to work the processes incrementally generated by the phases and roles that was detailed according to the meetings agreed in the process. However, the modifications that are presented can be done at any time since this framework allows us to do it both in the final part as well as in any of the deliverables or iterations as shown in Fig. 1 [13].
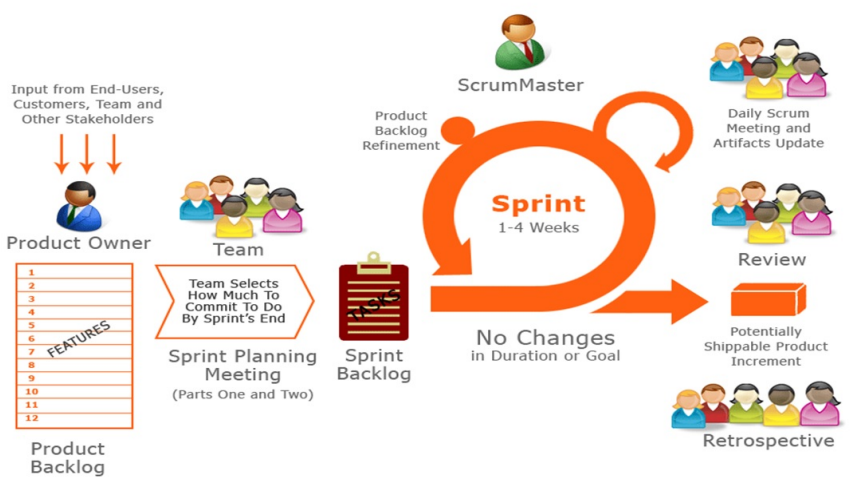

Fig. 1. Show Scrum Methodology [14].

\section{A. SCRUM Phases.}

They are the steps to follow for the development of a project. According to this framework, they are defined by times that guarantee the implementation of our mobile application and are as follows, as shown in Fig. 2.

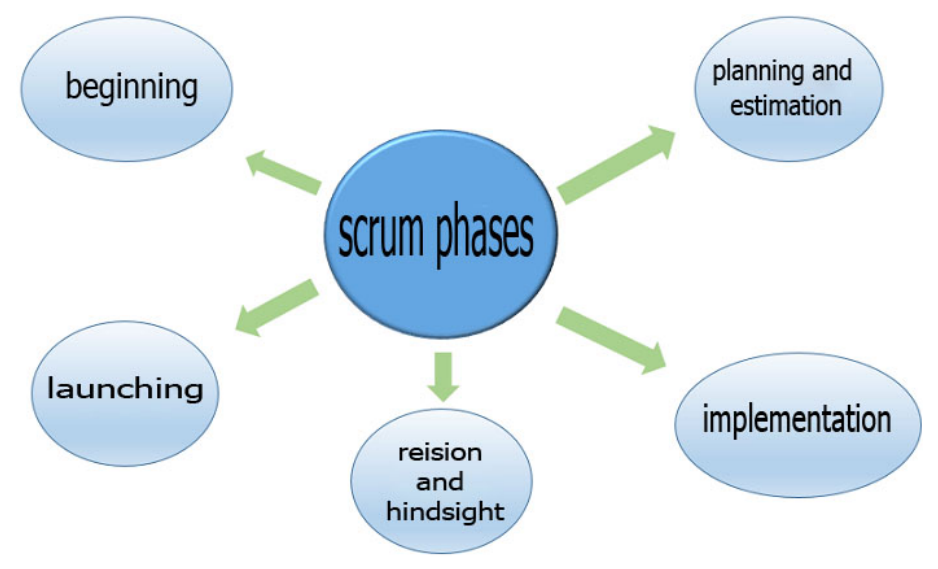

Fig. 2. Show the 5 Phases of Scrums

1) Beginning: It is where the research study begins, where the project is analyzed looking for the fundamental needs for each spring, which are the deliverables that was developed during the development of the project, in addition to asking questions such as: What do I want? How do I want? and When do I want? The vision and mission of the project must be created, identifying the Scrum master who was the leader of the group that has the necessary characteristics of a true leader.

2) Planning and Estimating: This stage is where it is created, in addition the user stories are identified, the user's requirements are studied, the iterations in which the mobile application was developed are created, considering that this 
is the most important phase of the project, where the master Scrum delegates the roles of each participant in the project.

3) Implementation: is considered the stage of greatest distress not only of skill but requires mental work, since the defined project begins to be created, in addition to reflecting the ideas given in the meetings where it was arranged how to optimize the work, in this stage the deliverables, as well as the necessary tests are carried out taking into account that at this stage no modifications should be made since this is seen in the planning stage, but because this methodology facilitates the developer to make the modifications in any of the iterations, could do it if it were the case and what would help improve the deliverables and therefore the project in general.

4) Review and Retrospective: In this stage, all the spring or deliverables are validated, where the work team has to carry out the necessary self-criticisms in addition to making the corresponding improvements to achieve the favorable scope of the work [15].

5) Launching: This is the last phase of the work, it is where the finished product has to be delivered to the client, achieving the best expectations, in addition to the acceptance of the end user.

\section{B. System Requirements}

These are all the requirements that allowed us to create the mobile application based on the information obtained to create the user requirements, having these requirements, the iterations were created.

Table 1 shows the user stories, which were raised according to the data collection, as can be seen, each story has an acceptance criterion which allows determining to what extent the advance of the mobile application is acceptable, this it was fulfilled by the work team, it also allows to reference the working mechanism behind so that the user can be satisfied. In addition, each user story has its description of the behavior of the application and its functionality.

\section{Product Creation Backlog}

This section is made up of a list of user stories or the requirements raised by the user that are ordered according to their priority in which they are estimated to become iterations.

Table II shown the iterations carried out during the application creation process. Accordingly, the iterations and deliverables will be analyzed.
TABLE I. ESTIMATION OF USER STORIES.

\begin{tabular}{|c|c|c|}
\hline User story & Description & criteria of acceptance \\
\hline Register User. & $\begin{array}{l}\text { As a user I need to create an } \\
\text { account to be able to use the } \\
\text { application with my username } \\
\text { and password. }\end{array}$ & $\begin{array}{l}\text { Register by mail or Google } \\
\text { account and be my username } \\
\text { and password. }\end{array}$ \\
\hline Login. & $\begin{array}{l}\text { As a user, I need to authen- } \\
\text { ticate my account using my } \\
\text { username and password to be } \\
\text { able to use the application. }\end{array}$ & $\begin{array}{l}\text { Login by email or Google ac- } \\
\text { count. }\end{array}$ \\
\hline $\begin{array}{l}\text { Show my lo- } \\
\text { cation on the } \\
\text { Map. }\end{array}$ & $\begin{array}{l}\text { As a user I need to self- } \\
\text { authenticate my account using } \\
\text { my username and password to } \\
\text { be able to use the application. }\end{array}$ & $\begin{array}{l}\text { Login via email or Google ac- } \\
\text { count. }\end{array}$ \\
\hline $\begin{array}{l}\text { Show current } \\
\text { city bike lanes. }\end{array}$ & $\begin{array}{l}\text { As a user I need to be able to } \\
\text { view the city bike lane. }\end{array}$ & $\begin{array}{l}\text { It allows you to view the city } \\
\text { bike lane network. }\end{array}$ \\
\hline $\begin{array}{l}\text { Search } \\
\text { Address. }\end{array}$ & $\begin{array}{l}\text { As a user I need to be able to } \\
\text { view the address I am looking } \\
\text { for to be able to move. }\end{array}$ & $\begin{array}{l}\text { Search through the address } \\
\text { drawn or by places where I } \\
\text { want to go. }\end{array}$ \\
\hline $\begin{array}{l}\text { Generate } \\
\text { default route } \\
\text { or select route } \\
\text { on the map. }\end{array}$ & $\begin{array}{l}\text { As a user i need to be able to } \\
\text { visualize the route that will be } \\
\text { generated to go safely. }\end{array}$ & $\begin{array}{l}\text { Generate the routes through } \\
\text { the bicycle lanes without us- } \\
\text { ing highly dangerous roads } \\
\text { and show the approximate } \\
\text { time that my trip will last. }\end{array}$ \\
\hline $\begin{array}{l}\text { Navigate dur- } \\
\text { ing the route. }\end{array}$ & $\begin{array}{l}\text { As a user I need to be able } \\
\text { to navigate during the route } \\
\text { through audio directions. }\end{array}$ & $\begin{array}{l}\text { Show the arrival time on } \\
\text { the screen, make directions } \\
\text { through the default Google } \\
\text { voice. }\end{array}$ \\
\hline $\begin{array}{l}\text { Create } \\
\text { Favorite } \\
\text { Destinations. }\end{array}$ & $\begin{array}{l}\text { As a user I need to be able } \\
\text { to create, edit and delete fa- } \\
\text { vorite places, this way to al- } \\
\text { low quick access without the } \\
\text { need to search for it. }\end{array}$ & $\begin{array}{l}\text { Show the list of favorite } \\
\text { places. }\end{array}$ \\
\hline $\begin{array}{l}\text { Register places } \\
\text { of interest or } \\
\text { tourist. }\end{array}$ & $\begin{array}{l}\text { As a user I need to be able to } \\
\text { view the address I am looking } \\
\text { for to move and to be able to } \\
\text { register it. }\end{array}$ & $\begin{array}{l}\text { Search through the back ad- } \\
\text { dress or by places where I } \\
\text { want to go. }\end{array}$ \\
\hline $\begin{array}{l}\text { Create custom } \\
\text { routes and be } \\
\text { able to save } \\
\text { them. }\end{array}$ & $\begin{array}{l}\text { As a user I need to be able to } \\
\text { create custom routes and use } \\
\text { them in future trips. }\end{array}$ & $\begin{array}{l}\text { The routes are assigned to } \\
\text { the menu create route, list the } \\
\text { routes. }\end{array}$ \\
\hline $\begin{array}{l}\text { Show notifica- } \\
\text { tions. }\end{array}$ & $\begin{array}{l}\text { As a user I need to be able } \\
\text { to view notifications related to } \\
\text { the application. }\end{array}$ & notifications must be used. \\
\hline $\begin{array}{l}\text { Application } \\
\text { options menu. }\end{array}$ & $\begin{array}{l}\text { As a user I need to be able to } \\
\text { view all the menu options. }\end{array}$ & $\begin{array}{l}\text { access by sliding to the main } \\
\text { menu. }\end{array}$ \\
\hline $\begin{array}{l}\text { Create shared } \\
\text { route. }\end{array}$ & $\begin{array}{l}\text { As a user I need to be able to } \\
\text { share my routes or trips that I } \\
\text { take as family, friends, as well } \\
\text { as other users to be able to } \\
\text { access shared routes. }\end{array}$ & $\begin{array}{l}\text { It must be shown in the routes } \\
\text { section created by the user. }\end{array}$ \\
\hline $\begin{array}{l}\text { Forgot } \\
\text { password. }\end{array}$ & $\begin{array}{l}\text { As a user I need to be able } \\
\text { to reset my password in case } \\
\text { I forget. }\end{array}$ & $\begin{array}{l}\text { To reset the password the app } \\
\text { will send a validation mes- } \\
\text { sage to the initially registered } \\
\text { email. }\end{array}$ \\
\hline
\end{tabular}

TABLE II. BACKLOG CREATION

\begin{tabular}{|l|l|l|l|}
\hline \multicolumn{1}{|c|}{ User story } & Estimate & Sprint & $\begin{array}{l}\text { Estimation } \\
\text { by sprint }\end{array}$ \\
\hline $\begin{array}{l}\text { Show my Location on the } \\
\text { map. }\end{array}$ & 3 & & \\
Show current bike lanes. & 5 & & \\
Search direction. & 5 & 1 & 34 \\
$\begin{array}{l}\text { Generate default route or se- } \\
\text { lect from map. }\end{array}$ & 5 & & \\
Navigate along the route. & 13 & 5 & \\
\hline $\begin{array}{l}\text { Register user. } \\
\text { Login. }\end{array}$ & 5 & 28 \\
$\begin{array}{l}\text { Forget password. } \\
\text { Register places of interest or } \\
\text { tourist. }\end{array}$ & 5 & & \\
\hline $\begin{array}{l}\text { Register Trips. } \\
\text { Show notifications. } \\
\text { Create Favorite destinations. }\end{array}$ & 5 & 3 & 21 \\
\hline $\begin{array}{l}\text { Create custom routes and save } \\
\text { them. }\end{array}$ & 9 & & \\
Application options menu. & 9 & 4 & 29 \\
Create shared routes. & 7 & & \\
\hline
\end{tabular}




\section{Application Planning}

As shown in Fig. 3, the Scrum phases that were implemented in the research were carried out, this helped to have more order in the work carried out and meeting the objective.

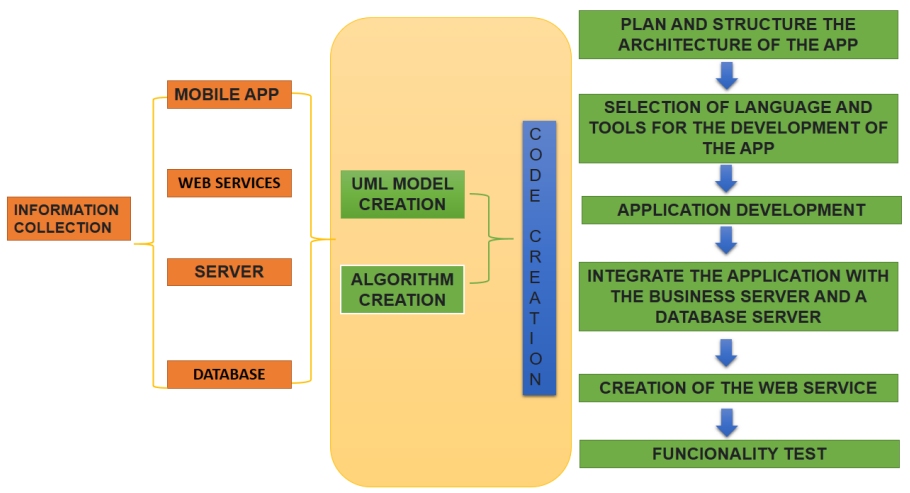

Fig. 3. Flow Chart using Scrum Methodology.

1) Planning and Structure of the Mobile Application: It is where the architecture of the work process for the implementation of the mobile application is defined, according to the data collected in the research references by the aforementioned authors and according to the data of the survey carried out.

2) Language Selection and Development Tools: At this stage, with the help of previous research, was seek to implement our new work mechanism, tools that are facilitators for the work to be carried out.

3) Application Development: According to what has been proposed, the developers will have established times for each iteration according to what was proposed in the meetings, in addition the planned times are from 2 to 8 days per iteration, during this process the mobile application is created progressively.

4) Integration of the App with the Business Server and the Database Server: At this stage the developers was the task of implementing the corresponding connections for their application functionality.

5) Creation of the Web Services: At this point the developers will start the communication process between the application with the database.

6) Tests: At the end of each iteration corresponding to each deliverable, the necessary tests were carried out for its compliance.

\section{E. Data Collection}

For the following investigation, 5 questions were formulated to around 50 people on the public road where some cyclists usually travel. In some cases it is possible to survey passers-by who do not travel by bicycle but who were interested in an application that helps them to use this means of transport. In addition, this helped to collect data and discover the interests of users or people who would suck in the future through this medium. The instrument was validated by the judgment of experts in the field; giving for approved the validation of the instrument.

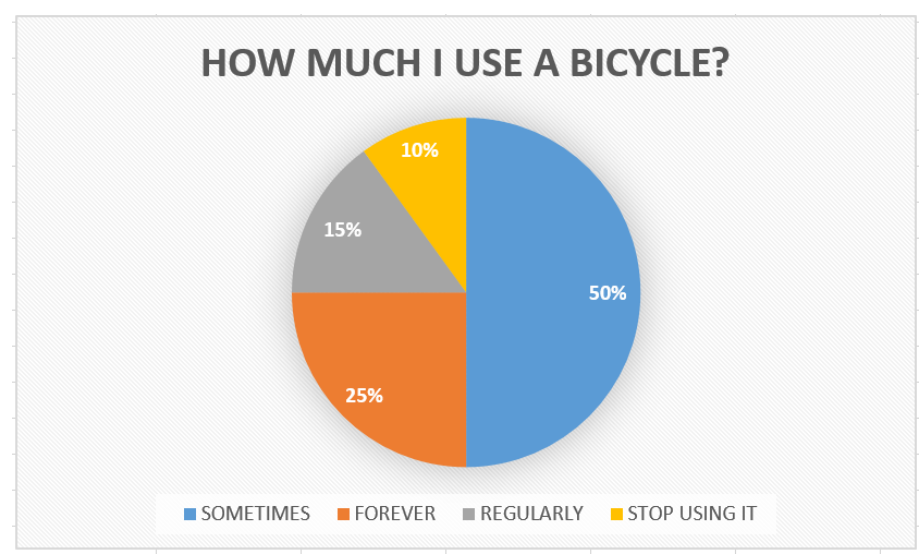

Fig. 4. Show Survey Results

Fig. 4 shows the statistical data of question number 1 in which the following results were obtained:

How much do you use a bicycle?

the responses were as follows:

- The equivalent of $50 \%$ of those surveyed answered that they sometimes use this medium.

- $\quad 25 \%$ of those surveyed answered that they always use. bicycle to move everywhere.

- $15 \%$ of those surveyed do it on a regular basis.

- $4 \%$ responded that they stopped using.

\section{F. Mobile Application Architecture}

For the design, the work team had to be previously assembled, likewise to propose the structure that the mobile application will have, carry out simple prototypes, define the services to be implemented, how it will work, in how many modules they will be carried out.

\section{G. Structure of the Application}

Fig. 5 shows the behavior of the application, where the final beneficiary is the cyclist, this had a web server, a database to store them, a messaging server, it will work with the satellite geolocator implementing free libraries, To use this tool, you must have a mid-range mobile device for use in addition to basic requirements.

\section{H. Tools for the Implementation of the App}

For the development of this application, different tools were used such as Android Studio, which is the platform where the application was encoded, the free libraries provided by Google maps were also used as geolocation tools, it also has a web service and a database data as detailed below.

1) Android studio

It is a programming software for the Android platform that contains all the necessary and explicit tools 


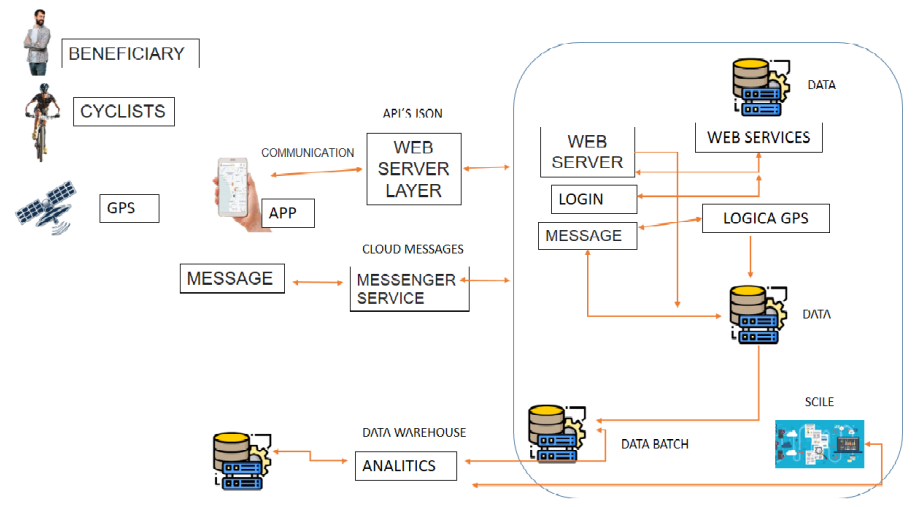

Fig. 5. Architecture of the Mobile App.

for the development of applications in this operating system (Android), it allows to carry out a number of configurations as well as import libraries.

2) Web services

It is an information system that exchanges XML-type messages with different systems that use different protocols such as HTTP [16], allowing communication between them.

3) Geolocation

precise location of the equipment or device, locate it directly on the search map from the satellite and bring it closer to the places closest to it [17], in order to provide the best service for it. be connected to the internet service for its operation to be able to process the chains in its interaction with the user regardless of the distance in which they are.

4) Database

The database system is in charge of managing the data generated in the application [18], which is used when necessary according to the will due to its data management capacity.

5) JSON

It is a simple data format that is used in programming for data exchange, this format is based on the JavaScript language, however it is very familiar to programmers because it uses different programming languages as a whole, facilitating their understanding [19].

6) Firebase

It is a type of database that allows synchronizing data in real time by storing it in the cloud, unlike other firebase, it does not use tables, much less records. But rather converts them into a JSON format with a password for each user at the same time, allows you to update the Data without the need to enter codes, they are simply saved or updated with the simple fact of being connected to the server [20].

7) OpenStreetMap

It is a free and editable map all over the world created by volunteer programmers with a free license with easy access to both the images of the map that at the same time can be related to devices that have GPS [11].

8) Photoshop
It is a graphic design software dedicated to the graphic industry due to its high quality of tools to execute all the editing processes that allow graphic editors to carry out more professional work.

\section{RESUlTS AND Discussions}

\section{A. Application Satisfaction}

According to the data obtained in the first survey that was carried out at the beginning of the project, the mobile application was implemented in order to solve the problems that the users expressed in their answers, as final results, the vast majority of positive responses were obtained in which gives the viability of this application. 5 questions were formulated to 50 people in order to test the application and how satisfactory its use is for end users, the results were the following:

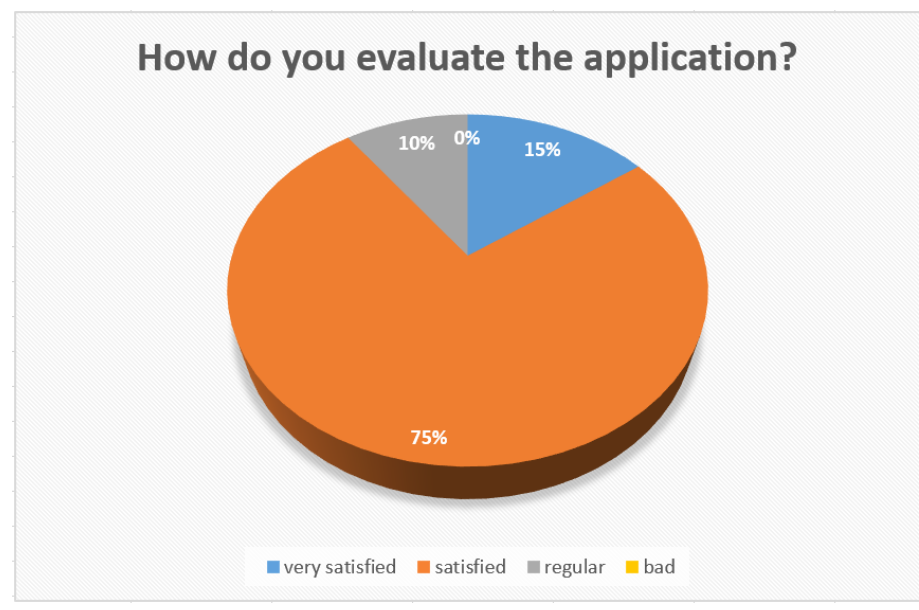

Fig. 6. Shows the Level of Satisfaction of the Application.

Fig. 6 shows the result of the survey carried out with 50 people on how satisfactory they found using the application, assigning them ratings such as: very satisfied, satisfied, fair, bad; getting a positive result as shown:

- $15 \%$ of people who are very satisfied.

- $75 \%$ of people who were satisfied with the application.

- The $10 \%$ that seemed regular to the application.

- A negative $0 \%$.

Fig. 7 shows the results of question number 2 in which the respondent was asked whether the experience of riding a bicycle using the application improved. The results were the following:

- $50 \%$ answered what is experience improved

- $30 \%$ responded that their experience was fair.

- $15 \%$ answered that they only improved a little more than usual.

- $5 \%$ answered that nothing improved.

Fig. 8 shows the results of question number 3 in which the respondent was asked, How does he familiarize himself with the application? The results were the following: 


\section{IMPROVED YOUR BIKE RIDING}

EXPERIENCE USING THE APP

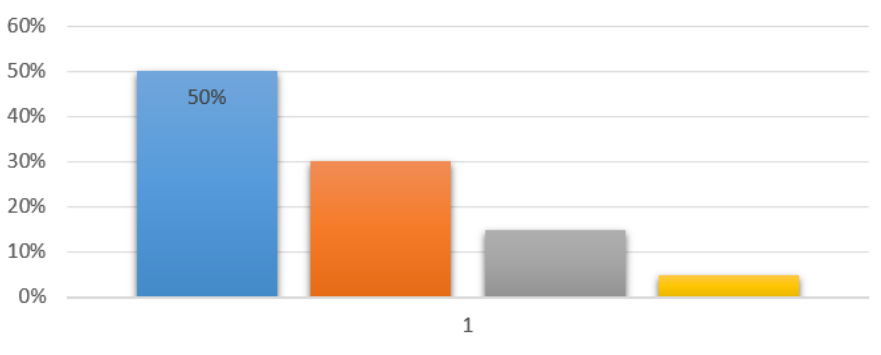

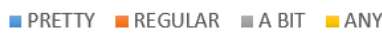

Fig. 7. Show the Results of Question 2.

\section{HOW DO YOU GET FAMILIAR WITH THE APPLICATION}

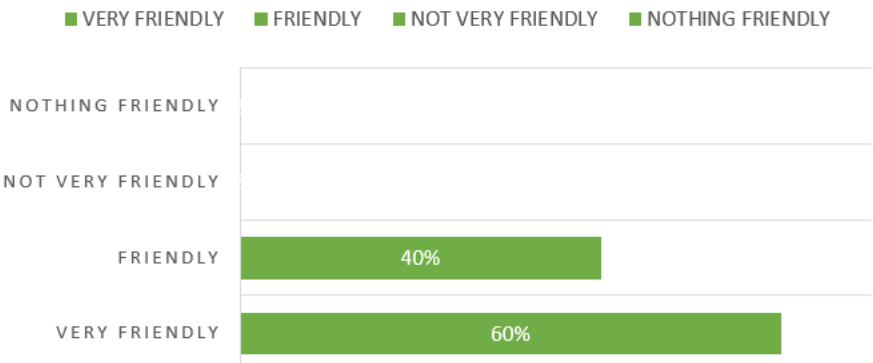

Fig. 8. Show the Results of Question 3.

- $\quad 60 \%$ define the application as very friendly and use.

- $\quad 40 \%$ defines the application friendly and use.

- The $0 \%$ defines how it is not very friendly and use of the application.

- $\quad 0 \%$ defines as not friendly and use of the application

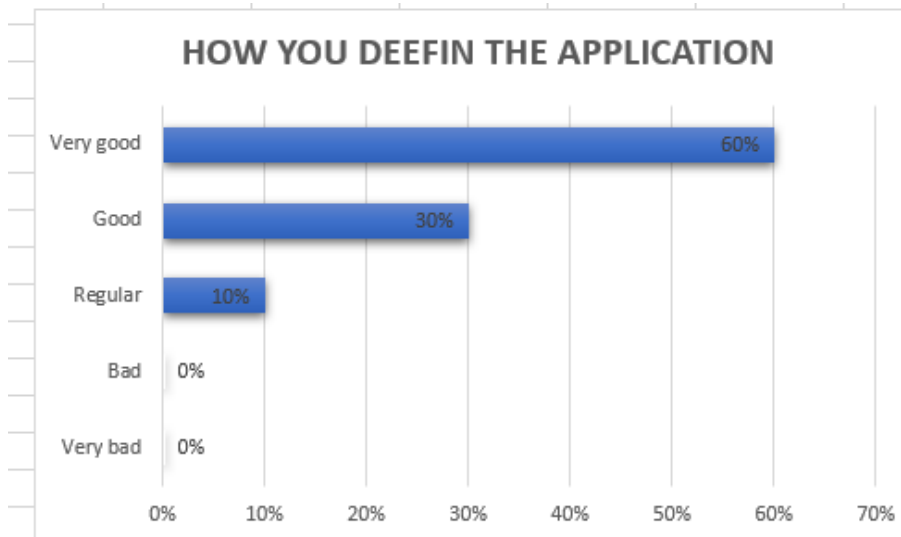

Fig. 9. Show the Results of Question 4.

Fig. 9 shows the results of question number 4 in which the respondent was asked, how do you define the application?
Having 5 alternatives in an ascending way, they could define it as very good, good, fair, bad and very bad.The results obtained reflect the effort of the work team to achieve the final objective and the results were the following:

- $60 \%$ answered defined it as very good

- $30 \%$ defines the application as good.

- The $10 \%$ defines the application as regular.

- $\quad 0 \%$ defines it as bad.

- $\quad 0 \%$ defines it as very bad.

\section{WOULD YOU RECOMMEND THE} APPLICATION

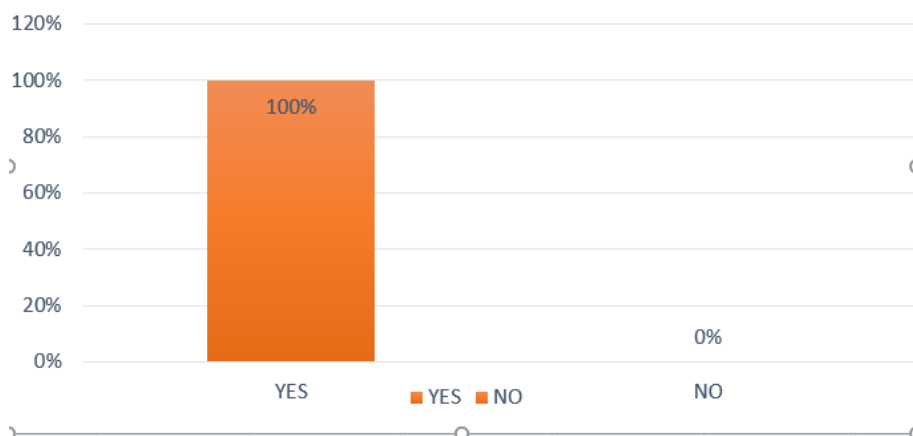

Fig. 10. Show the Results of Question 5.

In Fig. 10 shows the results of question number 5 in which the respondent was asked yes Would you recommend the application? The results were the following:

- $100 \%$ answered that they would recommend the application, which are very positive results for the project.

- $0 \%$ answered negatively.

\section{B. About the Methodology}

There are many alternatives to carry out research work which allows us to carry out large-scale projects. Scrum is a great and very significant alternative since it allows modifying in any part of the iterations without giving us complications, with reference to the [8] that use the Android operating system, surely the project in the future can be implemented to other mobile operating systems since it should not be limited to it.

As a work team we support the author [10], as it is an innovation system for society, in addition, it must be treated with the legal norms established by the executive as well as local and regional governments, who are responsible for its jurisdiction at the territorial level.

\section{Prototype}

For the creation of the prototype, the tool called Photoshop has been used, since being a graphic tool it allows to resemble the closest thing to reality. These prototypes were made according to the requirements of the system to be used as shown in the following figures. 
However, there are tools such as: PropApp, Marvel, Proto.io, Fluid, Balsamiq that also serve to make prototypes for mobile applications that could be implemented in the future [21], however Photoshop was chosen since it was an easily mastered tool, but the possibilities of the other tools are not ruled out since they also provide facilities for the developer who has greater command or in which he feels more comfortable working [22].

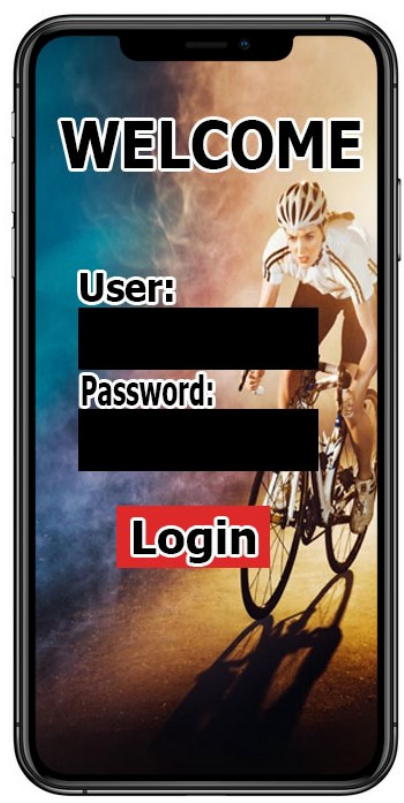

Fig. 11. Shows the Design of the Prototype of User Story No. 2.

Fig. 11 shows the design of the prototype of User Story No. 2, where the user when entering the application will show him this interface. Within this interface, the user will log in and thus will be able to authenticate their entry with their username and password, taking them to the main interface. If you are entering for the first time, you have the option of registering (CKEKIN IN), clicking this button takes you to another interface of the application.

Fig. 12 shows the design of the prototype of User History No. 1 where the new user registers for the first and only time, he will have to enter his personal data such as name, surname, email, password, address, cell phone. This record is validated with a message to your entered email or to the entered cell phone.

Fig. 13 shows the design of the prototype of User History No. 3 where the application allows through geolocation to show the user his exact location where he is, displaying it on the map.

Fig. 14 shows the design of the prototype of User History No.5, in this interface the application allows to search for an address entered by the user, through geolocation it will show the predetermined route so that the user can go to the place where they want move.

Fig. 15 shows the design of the prototype of User Story No.12 where the user has a menu of options in a dropdown located in the upper left part of the application such as configuration, create routes, see their trips, log out.

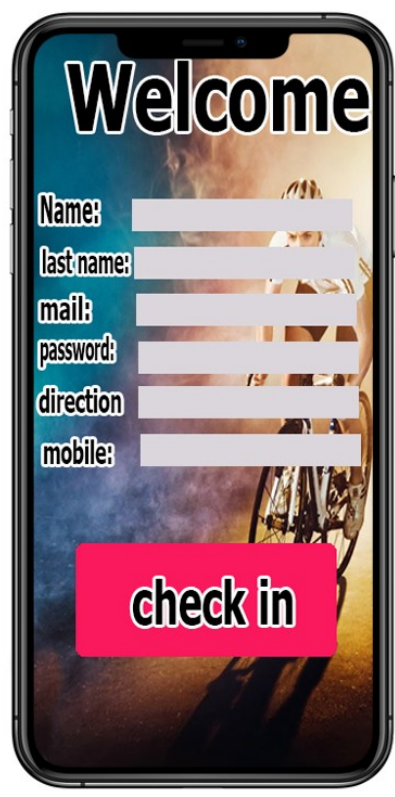

Fig. 12. Shows the Design of the Prototype of User Story No. 1.

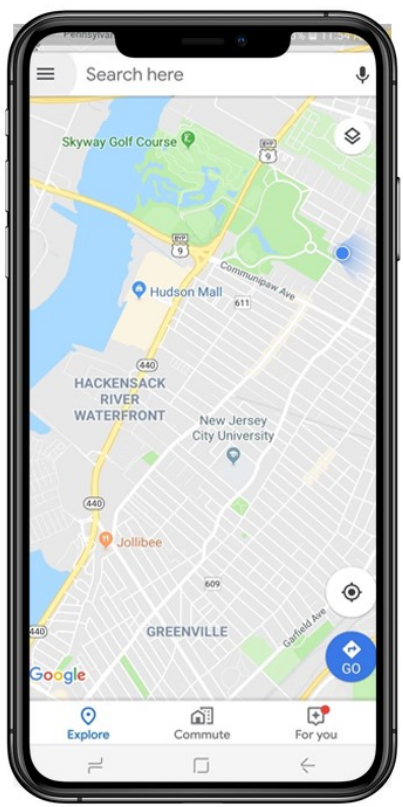

Fig. 13. Shows the Design of the Prototype of User Story No. 3.

Fig. 16 shows the design of the prototype of User History No.13 where the application shows the user the option to create their own route, it also allows them to save the route so that at another time they can access it and also allows them to share it with others users.

\section{CONCLUSiON}

It is concluded that regarding the development of the mobile application, it shows all the functional requirements of the system, in addition to complying with the iterations that were proposed by the developers in the initial meeting of the research framework. The Scrum methodology allowed 


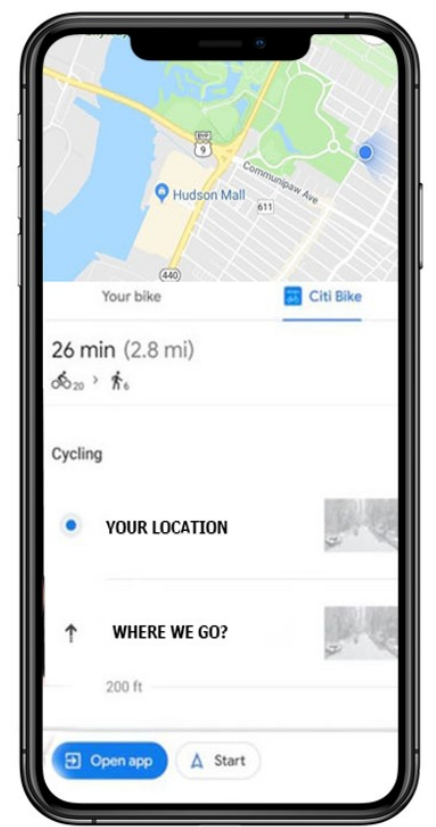

Fig. 14. Shows the Design of the Prototype of User Story No. 5.

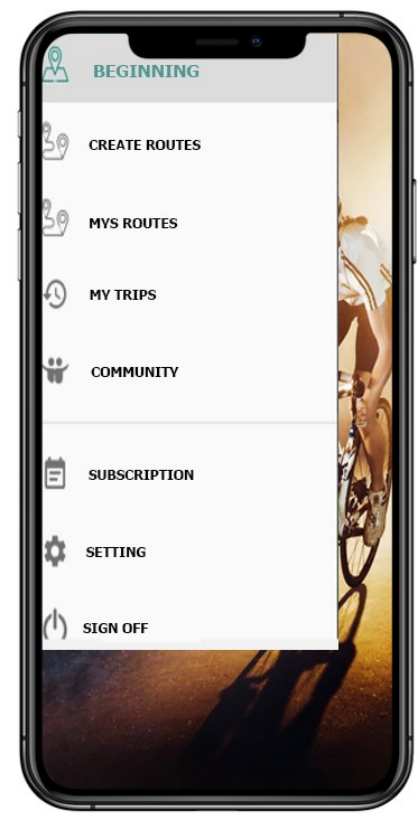

Fig. 15. Shows the Design of the Prototype of User Story No.12.

us to work with deliverables for each sprint, making quality prototypes for their development.

In its entirety in the survey carried out, people state that they would recommend the use of the application; that is to say that there is a satisfaction in the use they make of it. Some limitations were found, such as the little culture of the citizens for the use of bicycles on the routes; as well as the little support from the authorities to give priority to this issue.

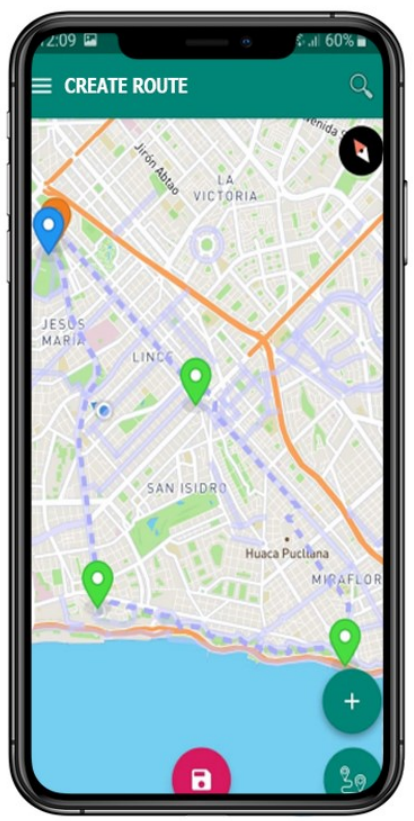

Fig. 16. Shows the Design of the Prototype of User Story No.13.

\section{FUTURE WORK}

For future work, it is recommended to use this research work and implement new ideas such as the development of the application implementation for the different platforms and operating systems that exist in the Peruvian market, you can also implement the application to use it at the level national and not only in a sector limited to its use, this work will help a lot for the next investigations to be developed.The use of bicycles contributed to the citizens, since using bicycles allows to reduce pollution and stress, which would be the subject of another study in the future.

\section{ACKNOWLEDGMENT}

Recognition is made for the support provided by the University of Sciences and Humanities, through its Research Center, so that the research carried out can be achieved.

\section{REFERENCES}

[1] M. Cabanillas-Carbonell, H. Paucarcaja-Ochoa, and O. Casazola-Cruz, "Analysis of the impact of ict for the management and control of public transport: A review of scientific literature from 2015 - 2020," in 2021 IST-Africa Conference (IST-Africa), 2021, pp. 1-9.

[2] A. C. Bazan Fachin, C. E. Calderon Mendoza, and C. S. Campos Salas, "Aplicativo móvil que ayudara a usuarios a trasladarse en bicicletas, scooters ya pie por rutas seguras y confiables: Move."

[3] J. A. Avalos Alfaro, J. J. Castro Palomino, V. L. Munoz Zumaran, D. A. Rubio Rotalde, and K. L. Silva Rivera, "Bicity-plataforma web y aplicativo móvil."

[4] S. R. Fajardo, L. F. Albán, and P. C. Guerrero, "Incidencia de las rutas de ciclismo en la demanda de turismo activo de naturaleza de los ciclistas que recorren la provincia del guayas. diseño de un aplicativo móvil de cicloturismo," Revista Empresarial, vol. 11, no. 44, pp. 7-12, 2017.

[5] A. Carrion-Silva, C. Diaz-Nunez, and L. Andrade-Arenas, "Admission exam web application prototype for blind people at the university of sciences and humanities," International Journal of Advanced Computer Science and Applications, vol. 11, no. 12, 2020. [Online]. Available: http://dx.doi.org/10.14569/IJACSA.2020.0111246 
[6] A. Tupia-Astoray and L. Andrade-Arenas, "Implementation of an e-commerce system for the automation and improvement of commercial management at a business level," International Journal of Advanced Computer Science and Applications, vol. 12, no. 1, 2021. [Online]. Available: http://dx.doi.org/10.14569/IJACSA.2021.0120177

[7] M. Alvariño Torres and D. A. Leiva López, "Implementación de una aplicación móvil bajo la plataforma android para promover el uso de la bicicleta en lima metropolitana en el año 2019," 2020.

[8] R. Arias-Marreros, K. Nalvarte-Dionisio, and L. Andrade-Arenas, "Design of a mobile application for the learning of people with down syndrome through interactive games," International Journal of Advanced Computer Science and Applications, vol. 11, no. 11, 2020. [Online]. Available: http://dx.doi.org/10.14569/IJACSA.2020.0111187

[9] S. Olivi, L. Luciana, Y. Lozano, D. Martín, J. Luz, G. Cerrón, and O. Miryana, "Aplicación de movilidad urbana : Smartbikes aplicacón de movilidad urbana :," pp. 0-107, 2020.

[10] A. José, A. Rivera, V. Asesora, M. Marfil, F. Ballvé, M. Del, J. M. C. Torres, H. M. Cesar, and Z. Loayza, "El uso de la bicicleta como alternativa de transporte sostenible e inclusivo para Lima Metropolitana,' p. 186, 2015.

[11] J. Alexander, M. Zamalloa, C. Descripción, and D. E. L. Problema, "Carrera Ingeniería Informática y de Sistemas Contenido," 2020.

[12] J. F. Cadavieco, "La interactividad de los dispositivos móviles geolocalizados , una nueva relación entre personas y cosas," no. October 2013, 2015.

[13] V. Gomero-Fanny, A. R. Bengy, and L. Andrade-Arenas, "Prototype of web system for organizations dedicated to e-commerce under the scrum methodology," International Journal of Advanced Computer Science and Applications, vol. 12, no. 1, 2021. [Online]. Available: http://dx.doi.org/10.14569/IJACSA.2021.0120152
[14] P. Deemer, G. Benefield, C. Larman, and B. Vodde, "Información básica de scrum," California: Scrum Training Institute, 2009.

[15] A. Ramos-Romero, B. Garcia-Yataco, and L. Andrade-Arenas, "Mobile application design with iot for environmental pollution awareness," International Journal of Advanced Computer Science and Applications, vol. 12, no. 1, pp. 566-572, 2021, cited By :3. [Online]. Available: https://doi.org/10.14569/IJACSA.2021.0120165

[16] J. Sandoval, RESTful Java Web Services. Packt Publishing, 2009, vol. 1.

[17] J. F. Cadavieco, "La interactividad de los dispositivos móviles geolocalizados , una nueva relación entre personas y cosas," no. October 2013, 2015.

[18] R. Elmasri and S. B. Navathe, Fundamentals of Database System, 2021.

[19] P. Bourhis, J. L. Reutter, and D. Vrgoč, "Json: Data model and query languages," Information Systems, vol. 89, p. 101478, 2020.

[20] I. Sudiartha, I. Indrayana, I. Suasnawa, S. Asri, and P. W. Sunu, "Data structure comparison between mysql relational database and firebase database nosql on mobile based tourist tracking application," in Journal of Physics: Conference Series, vol. 1569, no. 3. IOP Publishing, 2020, p. 032092.

[21] R. Leon-Ayala, G. G'omez-Cortez, and L. Andrade-Arenas, "Mobile application aimed at older adults to increase cognitive capacity," International Journal of Advanced Computer Science and Applications, vol. 12, no. 12, 2021. [Online]. Available: http://dx.doi.org/10.14569/IJACSA.2021.0121297

[22] J. Flores-Rodriguez and M. Cabanillas-Carbonell, "Mobile application for registration and diagnosis of respiratory diseases: a review of the scientific literature between 2010 and 2020," in 2020 International Conference on e-Health and Bioengineering (EHB), 2020, pp. 1-4. [Online]. Available: https://doi.org/10.1109/EHB50910.2020.9280282 